\title{
Antidiabetic Potential of Marine Brown Algae-a Mini Review
}

\author{
Thilina L. Gunathilaka $\mathbb{D}^{1}{ }^{1}$ Kalpa Samarakoon, ${ }^{2}$ Pathmasiri Ranasinghe, ${ }^{3}$ \\ and L. Dinithi C. Peiris $\mathbb{( D}^{1}$ \\ ${ }^{1}$ Department of Zoology, Faculty of Applied Sciences, University of Sri Jayewardenepura, Nugegoda 10250, Sri Lanka \\ ${ }^{2}$ National Science and Technology Commission, Dudley Senanayake Mawatha, Colombo 8 00800, Sri Lanka \\ ${ }^{3}$ Industrial Technology Institute, Halbarawa Gardens, Malabe 10115, Sri Lanka \\ Correspondence should be addressed to L. Dinithi C. Peiris; dinithi@sci.sjp.ac.lk
}

Received 20 February 2020; Accepted 16 April 2020; Published 25 April 2020

Academic Editor: Antonio Brunetti

Copyright ( 2020 Thilina L. Gunathilaka et al. This is an open access article distributed under the Creative Commons Attribution License, which permits unrestricted use, distribution, and reproduction in any medium, provided the original work is properly cited.

\begin{abstract}
Marine algae are an important source of bioactive metabolites in drug development and nutraceuticals. Diabetes mellitus is a metabolic disorder and the third leading cause of death worldwide due to lifestyle changes associated with rapid urbanization. Due to the adverse side effects of currently available antidiabetic drugs, search for an effective natural-based antidiabetic drug is important to combat diabetes and its complications. Therefore, in lieu with herbal drug development, it is important to find the potential benefits of seaweeds for the management of type 2 diabetes as they are underexplored yet in Sri Lanka. Among the marine seaweeds, natural bioactive compounds are abundant in brown algae with potentials in application as active ingredients in drug leads and nutraceuticals. Bioactive secondary metabolites are derived from numerous biosynthetic pathways of marine algae which contribute to various chemical and biological properties. Phlorotannins present in marine brown algae exhibited antidiabetic activities through different mechanisms such as the inhibitory effect of enzyme targets mainly by inhibiting the enzymes such as $\alpha$-amylase, $\alpha$-glucosidase, angiotensin-converting enzymes (ACE), aldose reductase, dipeptidyl peptidase- 4 , and protein tyrosine phosphatase 1B (PTP 1B) enzyme. In addition, phlorotannins derived from brown algae have the ability to reduce diabetic complications. Hence, the present review focuses on the different antidiabetic mechanisms of secondary bioactive compounds present in marine brown algae.
\end{abstract}

\section{Introduction}

Diabetes mellitus (DM) is a metabolic disorder linked with chronic hyperglycaemia due to the relative or absolute deficiency in insulin hormone [1]. It is the third leading cause of death worldwide associated with major complications such as diabetic nephropathy, neuropathy, retinopathy leading to adult blindness, and amputations due to diabetic foot ulcers [2]. Though several pathogenic processes are involved with diabetes, most cases of diabetes can be categorized into two types depending on the etiology. Type 1 is defined as insulin-dependent DM, while type 2 is defined as noninsulindependent DM. Type $1 \mathrm{DM}$ is associated with an absolute deficiency of insulin due to the autoimmune destruction of beta cells of the pancreas, which normally secrete insulin, whereas type $2 \mathrm{DM}$ is associated with a relative deficiency of insulin due to the insulin resistance caused by an unhealthy diet, sedentary lifestyle, and obesity [3]. Both types of DM have different clinical and pathological features. However, type $2 \mathrm{DM}$ is mostly prevalent among the world population, and it is associated with insulin resistance due to overproduction of glucose by the liver and underutilization of glucose by muscle and adipose tissues [4]. According to the recent WHO statistics, the world's diabetes population has increased up to 592 million by 2035 [5]. Among the two types of DM, type $1 \mathrm{DM}$ is more common in the Northern European countries, whereas type 2 is most common in Africa and South Asian countries [6]. Hence, type 2 DM is 
mostly prevalent in Sri Lanka. In addition, more than 471 billion US dollars is spent annually worldwide for health care expenditure in diabetes patients and Sri Lankan government spend around 144 million US dollars annually to manage DM [7]. Therefore, DM not only affects the lives around world but also causes serious financial burden.

Owing to the pathogenesis of type $2 \mathrm{DM}$, insulin resistance is the main cause which leads to the development of type $2 \mathrm{DM}$. Insulin resistance is mostly developed in obese individuals than normal, and it can compensate with the overproduction of insulin by the $\beta$ cells of the pancreas. Due to the overproduction of insulin, $\beta$ cell functions will be impaired and will ultimately lead to chronic postprandial hyperglycaemia and fasting hyperglycaemia. Chronic hyperglycaemia can further diminish the function of $\beta$ cells and enhance the status of insulin resistance [8]. In addition to chronic hyperglycaemia, type $2 \mathrm{DM}$ is associated with dyslipidemia which affect the normal process of lipid metabolism [9]. Therefore, therapeutic strategies for type 2 DM should be developed to normalize the glucose metabolism and long-term complications.

Currently available therapeutic interventions for type 2 diabetes mellitus such as insulin administration and oral antidiabetic drugs have either limited efficacy or detrimental side effects [10]. Therefore, it is essential to keep searching for an effective drug that may benefit patients suffering from type $2 \mathrm{DM}$ which leads towards the curing of these patients. So far, none of the drugs that are used to treat type 2 DM have full efficacy, nor have the scientific investigations yielded any potential drug for proper therapy. Therefore, there is an increase need in search for the new plant-based compounds with minimum or no side effects to the patients. Recourses from plant materials pose less chemical hazards and are proved to be an efficient application. Phytochemical compounds in plant extracts are known to contain a secondary metabolite that can be used effectively to manage various diseases including diabetes mellitus [11].

In addition to the medicinal plants, natural bioactive compounds are abundant in marine algae with potential active ingredients in the treatment of type 2 diabetes mellitus [12]. Therefore, in lieu with herbal drug development with minimum side effects and the high economic cost benefit, identification of chemical components and isolation of the active compounds in less utilized marine algae are of high importance. In particular, most of the brown algae are rich in important secondary metabolites such as phlorotannins which are reported to have an antidiabetic activity [13]. Therefore, the purpose of this review is to focus on the diverse antidiabetic mechanisms of brown algal compounds and their possible use in pharmaceutical industry.

\section{Therapeutic Targets for Type 2 Diabetes Mellitus}

Reduction of postprandial hyperglycaemia is one of the main therapeutic interventions to treat type 2 DM [14]. Postprandial hyperglycaemia can be reduced by inhibiting the carbohydrate-hydrolysing enzymes such as $\alpha$-amylase and $\alpha$-glucosidase. Alpha amylase and $\alpha$-glucosidase are the important exo-acting glycoside hydrolase enzymes involved in the digestion of carbohydrates, and they act synergistically to digest starch in the human body. Alpha amylase breaks down the large insoluble starch by hydrolysing the alpha bonds, while $\alpha$-glucosidase catalyses the end step of digestion of starch and disaccharides into glucose subunits. Therefore, the inhibition of such enzymes leads to the reduction of postprandial blood glucose level and these enzyme inhibitors act as a potential target for the development of antidiabetic drugs [15].

In addition to the carbohydrate-hydrolysing enzymes, the inhibition of enzymes such as aldose reductase, angiotensinconverting enzymes, dipeptidyl peptidase-4, and protein tyrosine phosphatase $1 \mathrm{~B}$ can also be applied to the development therapeutic strategy to treat type $2 \mathrm{DM}[16,17]$. Aldose reductase is a key metabolic enzyme involved in the polyol pathway which converts glucose into the sorbitol in the presence of NADPH as a cofactor. Hyperglycaemia in type 2 DM results in an overproduction of sorbitol through the polyol pathway. High intracellular accumulation of sorbitol leads to the development of cataract and diabetic neuropathy [18]. Therefore, inhibitors of aldose reductase can prevent the formation of sorbitol through the polyol pathway and reduce long-term diabetes complications.

The angiotensin-converting enzyme is involved with the renin-angiotensin-aldosterone system which converts angiotensin 1 into angiotensin II. Angiotensin II is a potent vasoconstrictor, and it stimulates the secretion of aldosterone by the adrenal cortex and increases sodium and water absorption. The activation of the renin-angiotensin-aldosterone system increased blood pressure, which causes microvascular and macrovascular complications in patients with type 2 DM [19]. Therefore, inhibitors of angiotensin-converting enzyme have the ability to lower the blood pressure, thus helping to diminish the long-term diabetic complications. Similarly, dipeptidyl peptidase- 4 is an enzyme involved in glucose metabolism and helps to reduce incretin levels, such as glucose-like peptide-1 (GLP-1). GLP-1 is a gut hormone involved in the reduction of blood glucose level by stimulating insulin secretion during the hyperglycaemic conditions in patients with type $2 \mathrm{DM}$, whereas the effect of GLP-1 on insulin secretion progressively diminishes once the patient becomes euglycaemic [17]. Therefore, inhibitors of dipeptidyl peptidase-4 increase GLP-1 level which stimulates insulin secretion, thus helping to maintain hyperglycaemic conditions in patients with type $2 \mathrm{DM}$ (Figure 1).

Protein tyrosine phosphatase 1B (PTP 1B) is another enzyme which is involved in the insulin signalling pathway and located on the cytoplasmic face of the endoplasmic reticulum. [20]. PTP 1B enzyme is a negative regulator of the tyrosine phosphorylation cascade which is directly involved with the insulin signalling pathway. The binding of insulin to insulin receptor causes structural changes in the receptor through the autophosphorylation of tyrosine residues within the cells, which subsequently activate the different pathways to increase glucose uptake to the cells. During this process, PTP 1B enzyme alters the insulin receptor phosphorylation and counteracts insulin signalling. Therefore, the inhibition of this enzyme leads to the reduction of the blood glucose 


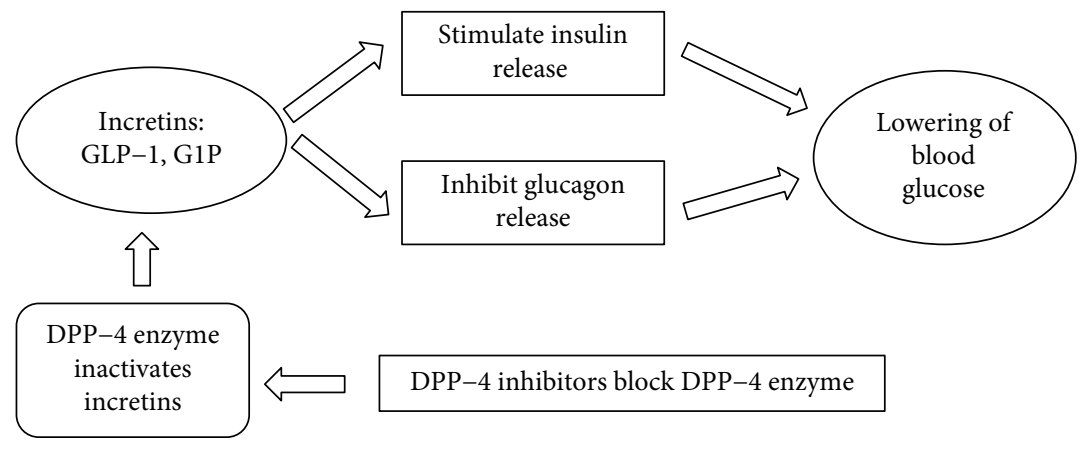

FIgURE 1: Action of DPP-4 inhibitors on glucose homeostasis.

level by increasing the insulin sensitivity; thus, protein tyrosine phosphatase $1 \mathrm{~B}$ inhibitors can be used as a potential target for the treatment of type $2 \mathrm{DM}$ [21].

Chronic hyperglycaemia in diabetic patients leads to the formation of advanced glycation end products which is associated with the pathogenesis of vascular complications in diabetes, renal failure, Alzheimer's disease, aging, and other chronic diseases. Formation of advanced glycation end products is a complex process, which involves the nonenzymatic reaction between the carbonyl group of a glucose molecule and free amino groups which leads to the formation of a nonstable Schiff base and Amadori products through reversible reactions. Further rearrangement of the Schiff base and Amadori products leads to the formation of advanced glycation end products through irreversible reactions [22]. Therefore, the natural compounds which inhibit the formation of advanced glycation end products can be used to suppress the diabetic complications associated with the accumulation of advanced glycation end products.

\section{Bioactive Compounds Present in Marine Brown Algae}

Marine macroalgae have been widely studied in the last few years due to the presence of human beneficial bioactive components. Marine seaweeds are a group of macroscopic and multicellular species living in the marine environment. Among them, macroalgae are large aquatic photosynthetic plants found in the coastal areas and they are visible to the naked eye. They have a high growth rate during the cultivation in sea water. Depending on the pigment they contain, macroalgae are classified as red algae (Rhodophyta), green algae (Chlorophyta), and brown algae (Phaeophyta) [23] Among the marine seaweeds, around 1500-2000 species of marine brown algae are available and most of the brown algal species are subjected to research purposes due to their commercial significance in drug leads and nutraceuticals. In particular, most important secondary bioactive metabolites such as phlorotannins, fucosterols, fucoidans, alginic acids, fucoxanthin, and phycocolloids have been extensively found in brown algae, which exhibit significant biological properties including antidiabetic, anti-inflammatory, cytotoxic, and antioxidant activities [24]. Here, we focus on the researches conducted worldwide to determine the antidiabetic activities of marine brown algae.

Phlorotannins are polyphenolic secondary metabolites derived from phloroglucinol and present mainly in marine brown algae. Phlorotannins are made up of repeating subunits of phloroglucinol linked in several ways. The antioxidant activity exhibited by phlorotannins is mainly linked with molecular skeleton which is consist of phenol rings [24]. As the oxidative stress is tightly linked with the pathophysiological process of diabetes mellitus, phlorotannins present in marine brown algae can be used to combat oxidative stress and diabetes mellitus [25]. Several types of phlorotannins are present in different algal species, and they can be classified into six subgroups such as phlorethols, fuhalols, fucols, fucophlorethols, eckols, and carmalols based on the type of linkage between phloroglucinol units and hydroxyl groups present on the phenol rings [24]. The chemical structure of phloroglucinol and six subgroups is shown in Figure 2.

In addition to the phlorotannins, brown algae produce different types of polysaccharides such as fucoidans, alginates, and laminarans. Fucoidans and laminarans are water-soluble sulphated polysaccharides, whereas alginic acid is an alkalisoluble polysaccharide present in brown algae. Sulphated polysaccharides present in marine brown algae have been reported to possess various biological activities with effective therapeutic effects. Fucoidan has been reported to exhibit antioxidant, antidiabetic, and anti-inflammatory activities, whereas laminarans play a role as prebiotics and dietary fibers in addition to their antibacterial and antitumor activities. Alginic acids are mostly used in the pharmaceutical industries due to the ability to chelate the metal ions [23]. Moreover, fucosterols are the predominant sterol present in brown algae also exhibit biological properties [13]. The structure of fucoidan, laminarans, alginic acid, and fucosterols is presented in Figure 3.

Further, fucoxanthin is the accessory pigment and most abundant carotenoid present in the marine brown seaweeds and which was primarily isolated from the brown seaweeds Fucus, Dictyota, and Laminaria. The molecular structure of the fucoxanthin is given in Figure 3. Fucoxanthin has been reported to possess strong biological activities such as antioxidant, anticancer, and antidiabetic activities, mainly due to the unusual allenic bond and oxygenic functional group in its structure [26]. 
<smiles>Oc1cc(O)cc(O)c1</smiles>

Phloroglucino

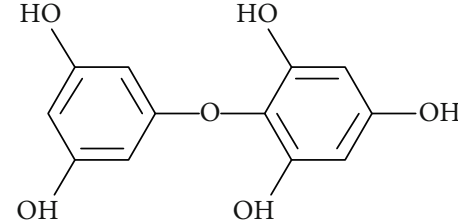

Phlorethols<smiles>Oc1cc(O)cc(Oc2c(O)cc(O)c3c2Oc2c(O)cc(O)cc2O3)c1</smiles>

Eckol<smiles>Oc1cc(O)cc(Oc2c(O)cc(O)c(-c3c(O)cc(O)cc3O)c2O)c1</smiles>

Fucol<smiles>Oc1cc(O)cc(Oc2c(O)cc(Oc3c(Oc4c(O)cc(O)cc4O)cc(O)c(O)c3O)cc2O)c1</smiles><smiles>Oc1cc(O)c2c(c1)Oc1c(O)cc(Oc3cc(O)c(O)c(O)c3)c(O)c1O2</smiles>

FIgURE 2: Chemical structure of phloroglucinol and groups of phlorotannins.

\section{In Vitro and In Vivo Antidiabetic Potentials of Marine Brown Algae}

The antidiabetic potential of marine macroalgae has been widely studied in the last few years due to the presence of bioactive components as mentioned above. Some of the studied brown marine algal species for their antidiabetic effects are shown in Figure 4. Among the bioactive compounds present in brown algae, phlorotannins have been identified as a potential source for the treatment of several human diseases including type $2 \mathrm{DM}$. As mentioned, the above six subgroups of phlorotannins are present in different species of brown algae, which possess significant antidiabetic action through several mechanisms [27]. In addition to the in vitro antidiabetic activity of marine brown algae, in vivo antidiabetic potential was evaluated using animal models to confirm the hypoglycaemic effect by different mechanisms [28].

4.1. Inhibitory Activity of $\alpha$-Amylase and $\alpha$-Glucosidase Enzymes. Most of the brown seaweeds which belong to the genus Ecklonia and family Lessoniaceae have been reported to exhibit antidiabetic activities mainly through the inhibitory action of $\alpha$-amylase and $\alpha$-glucosidase enzymes due to the presence of different phlorotannins such as eckol, dieckol, 6,6' -bieckol, phlorofucofuroeckol-A, phloroglucinol, and 7phloroeckol [29]. The methanol extract of Ecklonia cava exhibited potent antidiabetic activity through the inhibitory action on $\alpha$-glucosidase enzyme $\left(\mathrm{IC}_{50}-10.7 \mu \mathrm{M}\right)$ compared to the standard acarbose due to the presence of phlorotannin compounds, namely, dieckol, fucodiphloroethol G, 6,6 ${ }^{\prime}$ bieckol, 7-phloroeckol, and phlorofucofuroeckol-A [29]. Similar phlorotannins were isolated from the methanol extract of Ecklonia stolonifera reported to possess an inhibitory activity against $\alpha$-glucosidase enzymes which was attributed to the presence of phlorofucofuroeckol-A, dieckol, and 7-phloroeckol [29]. Furthermore, among the isolated phlorotannins, phlorofucofuroeckol-A $\left(\mathrm{IC}_{50}: 1.37 \mu \mathrm{M}\right)$ and dieckol $\left(\mathrm{IC}_{50}: 1.61 \mu \mathrm{M}\right)$ were found as the most effective inhibitors against the $\alpha$-glucosidase enzyme compared to the reference drug acarbose $\left(\mathrm{IC}_{50}: 51.65 \mu \mathrm{M}\right)$ [20]. The phlorotannin eckol $\left(\mathrm{IC}_{50}: 11.16 \mu \mathrm{M}\right)$ isolated from Ecklonia maxima exhibited the potent $\alpha$-glucosidase inhibitory activity compared to the phloroglucinol $\left(\mathrm{IC}_{50}: 1991 \mu \mathrm{M}\right)$ [20]. Similarly, fucofuroeckol-A and dioxinodehydroeckol isolated from Ecklonia bicyclis were also reported to have an inhibitory effect on $\alpha$-amylase and $\alpha$-glucosidase enzymes [20]. Moreover, a significant reduction of the postprandial blood glucose level was observed by the isolated phlorotannins, dieckol, and diphlorethohydroxycarmalol in both normal and diabetesinduced mouse groups [29].

In addition to the Ecklonia species, brown seaweeds belong to the genus Eisenia also possess strong antidiabetic activity by inhibiting $\alpha$-amylase and $\alpha$-glucosidase enzymes [30]. Eckol, dieckol, and 7-phloroeckol isolated from Eisenia 


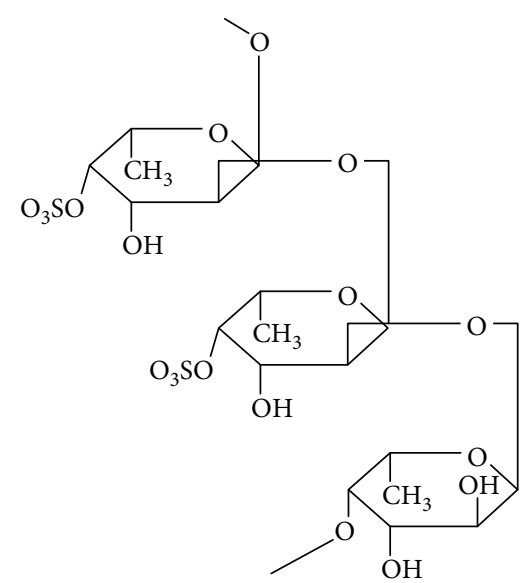

Fucoidan

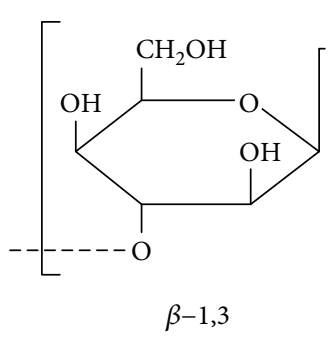

Laminaran

(b)<smiles>C/C=C(/CC[C@H](C)C1CCC2C3CC=C4C[C@@H](O)CCC4(C)C3CCC21C)C(C)C</smiles>

(c)

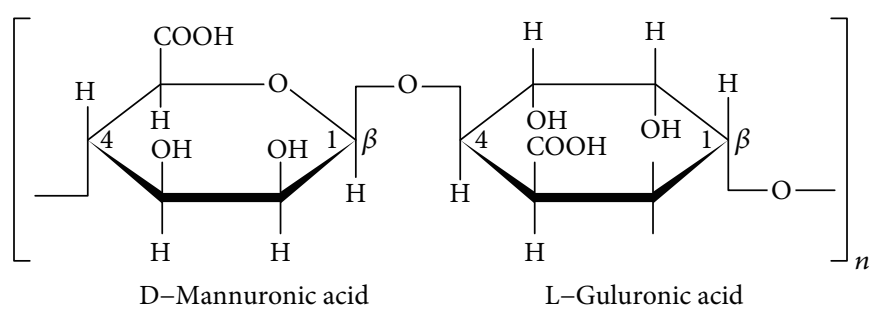

Alginic acid

(d)<smiles>CC(=O)O[C@@H]1CC(C)(C)C(=C=C=CC(C)=CC=CC(C)=CC=CC=C(C)C=CC=C(C)C(=O)C[C@]23O[C@]2(C)C[C@@H](O)CC3(C)C)[C@](C)(O)C1</smiles>

Fucoxanthin

(e)

Figure 3: Structural unit of (a) fucoidan, (b) laminaran, (c) alginic acid, (d) fucosterol, and (e) fucoxanthin.

bicyclis also strongly inhibit the $\alpha$-amylase enzymes by $87 \%$ at $1 \mathrm{mM}$ of concentration in addition to the inhibitory activity on $\alpha$-glucosidase enzyme and formation of advanced glycation end products [30]. Further studies confirmed that the $\alpha$-glucosidase inhibitory activity of eckol $\left(\mathrm{IC}_{50}: 22.78 \mu \mathrm{M}\right)$ is greater than the dioxinodehydroeckol $\left(\mathrm{IC}_{50}: 34.60 \mu \mathrm{M}\right)$ and phloroglucinol $\left(\mathrm{IC}_{5}: 141.18 \mu \mathrm{M}\right)$ whereas the $\alpha$-amylase inhibitory activity of fucofuroeckol $\mathrm{A}\left(\mathrm{IC}_{50}: 42.91 \mu \mathrm{M}\right)$ is stronger than the dioxinodehydroeckol $\left(\mathrm{IC}_{50}: 472.70 \mu \mathrm{M}\right)$ isolated from Eisenia bicyclis [20].

Ishige okamurae is a marine brown alga that belongs to the family Ishigeaceae and reported to have a potent antidia- betic activity through the mechanism of $\alpha$-amylase and $\alpha$ glucosidase inhibition. Recent studies have found that Ishige okamurae are rich in phlorotannins such as phloroglucinol, diphlorethohydroxycarmalol, 6-6-bieckol, octaphlorethol A, and ishophloroglucin which are responsible for the antioxidant and antidiabetic activities [28]. Among them, 6,6 ${ }^{\prime}$ bieckol and diphlorethohydroxycarmalol showed the potent antioxidant activity which was measured by $\mathrm{DPPH}$ radical scavenging activity with $\mathrm{IC}_{50}$ values of $9.1 \pm 0.4 \mu \mathrm{M}$ and $10.5 \pm 0.5 \mu \mathrm{M} 268$, respectively [28]. In addition, diphlorethohydroxycarmalol present in Ishige okamurae showed a potent inhibitory action against $\alpha$-amylase $\left(\mathrm{IC}_{50}=0.53 \pm\right.$ 


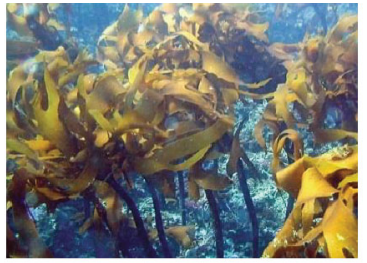

Ecklonia cava

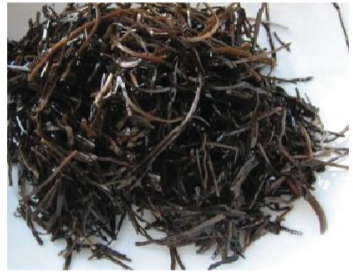

Eisenia bicyclis

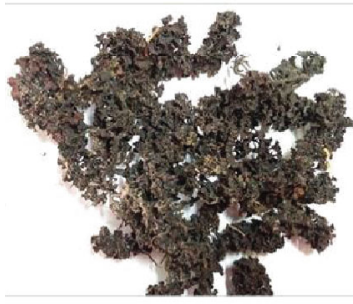

Turbinaria conoides

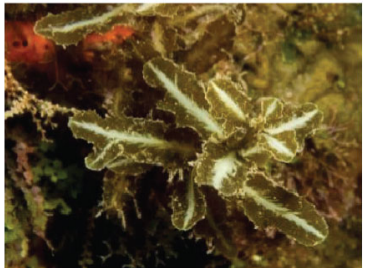

Ascophyllum nodosum

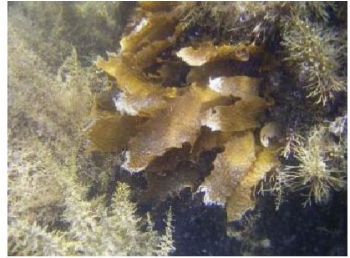

Ecklonia stolonifera

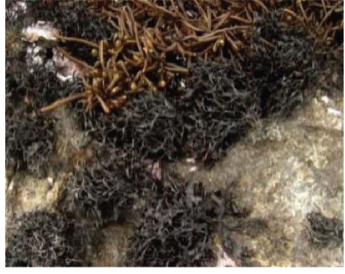

Ishige okamurae

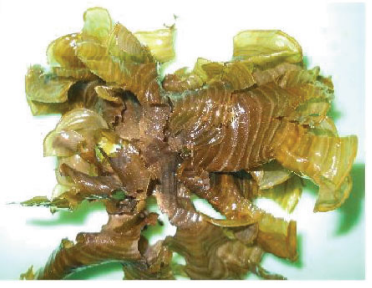

Padina tetrastromatica

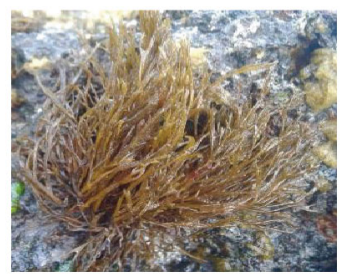

Choonospora minima

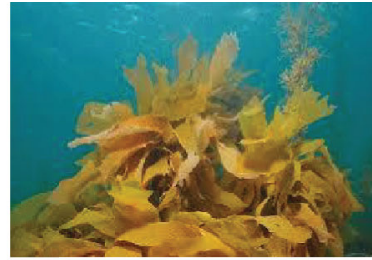

Ecklonia maxima

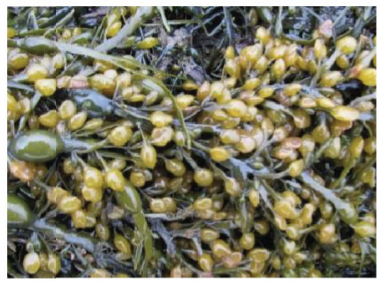

Sargassum polycystum

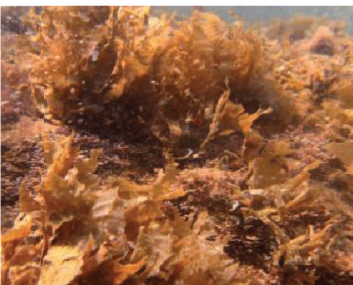

Padina boergesenii

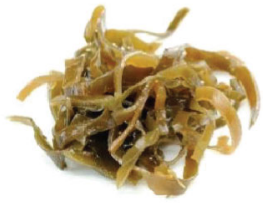

Saccharina japonica

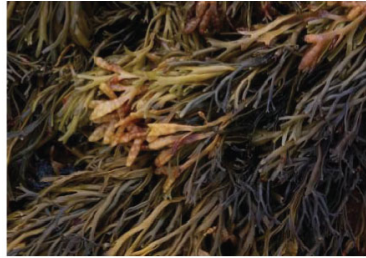

Ecklonia bicyclis

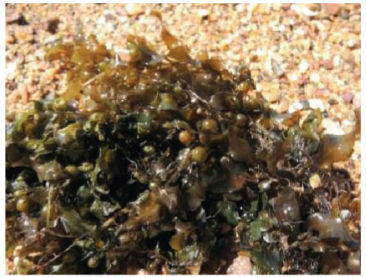

Sargassum hystrix

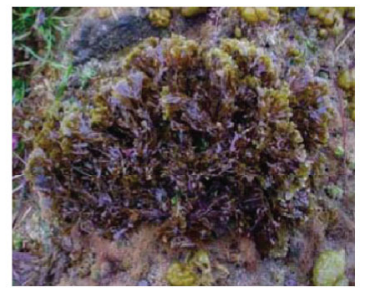

Dictyopteris undulata

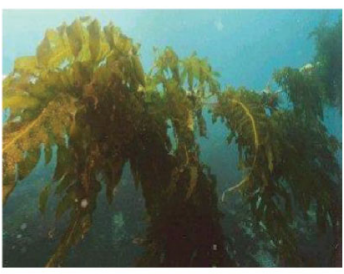

Undaria pinnatifida

Figure 4: Some of the studied brown algal species for their antidiabetic effects.

$0.08 \mathrm{mM})$ and $\alpha$-glucosidase $\left(\mathrm{IC}_{50}=0.16 \pm 0.01 \mathrm{mM}\right)$ to the standard drug acarbose $\left(\mathrm{IC}_{50}=1.10 \pm 0.07 \mathrm{mM}\right.$ and $1.05 \pm$ $0.03 \mathrm{mM})$ [28].

Nwosu et al. [31] investigated the hypoglycaemic effect of brown algae Ascophyllum nodosum by means of $\alpha$-amylase and $\alpha$-glucosidase inhibitory effects. According to the results, Ascophyllum nodosum extract showed an effective inhibitory activity on $\alpha$-amylase enzyme with an $\mathrm{IC}_{50}$ value of $0.1 \mu \mathrm{g} / \mathrm{ml}$, and further, it triggered a complete inhibition of the $\alpha$-amylase enzyme at $2-5 \mu \mathrm{g} / \mathrm{ml}$. In addition, the Ascophyllum nodosum extract inhibited the $\alpha$-glucosidase enzyme effectively with an $\mathrm{IC}_{50}$ value of $19 \mu \mathrm{g} / \mathrm{ml}$ compared to the standard drug acarbose $\left(\mathrm{IC}_{50}: 0.8 \mu \mathrm{g} / \mathrm{ml}\right)$. Further fractionation and LC-MS analysis revealed the presence of a series of phlorotannin structures in the Ascophyllum nodosum extract which exhibit the inhibitory activity on $\alpha$-amylase and $\alpha$-glucosidase enzymes [31].

The phlorotannins present in marine brown algae Sargassum hystrix have been subjected to determine the hypoglycaemic effect through the inhibitory activity of carbohydratehydrolysing enzymes. According to the results, Sargassum hystrix exhibited the potent inhibitory action on $\alpha$-amylase $\left(\mathrm{IC}_{50}: 0.58 \pm 0.01 \mathrm{mg} / \mathrm{ml} ; \mathrm{IC}_{50}\right.$ acarbose $: 0.53 \pm 0.00 \mathrm{mg} / \mathrm{ml}$; and $\mathrm{IC}_{50}$ phloroglucinol $\left.: 0.56 \pm 0.01 \mathrm{mg} / \mathrm{ml}\right)$ and $\alpha$-glucosidase $\left(\mathrm{IC}_{50}: 0.59 \pm 0.02 \mathrm{mg} / \mathrm{ml} ; \mathrm{IC}_{50}\right.$ acarbose $: 0.61 \pm 0.01 \mathrm{mg} / \mathrm{ml}$; and $\mathrm{IC}_{50}$ phloroglucinol: $0.56 \pm 0.05 \mathrm{mg} / \mathrm{ml}$ ) enzymes compared to the standard acarbose and phloroglucinol [32]. Further, the antidiabetic activity of Sargassum hystrix has been confirmed using streptozotocin-induced rats [33]. The results revealed that Sargassum hystrix has reduced preprandial $(186.4 \mathrm{mg} / \mathrm{ml})$ and postprandial $(186.9 \mathrm{mg} / \mathrm{ml})$ blood glucose levels significantly in diabetic rat groups at a concentration of $300 \mathrm{mg} / \mathrm{kg}$ compared to the reference drug glibenclamide at a dose of $5 \mathrm{mg} / \mathrm{kg}$ (preprandial glucose level $(195.6 \mathrm{mg} / \mathrm{ml})$ : postprandial glucose level $(104.8 \mathrm{mg} / \mathrm{ml}))$ without any effect on the body weight of streptozotocininduced diabetes rats [33].

Similarly, the edible seaweed Sargassum polycystum has been studied to evaluate the hypoglycaemic effect of streptozotocin-induced type 2 diabetic rats [34]. According to the results, ethanol $(150 \mathrm{mg} / \mathrm{kg})$ and aqueous $(300 \mathrm{mg} / \mathrm{kg})$ extracts of Sargassum polycystum significantly reduce the blood glucose level in diabetic rats by $27.8 \%$ and $35.2 \%$ compared to the diabetic rats treated with $250 \mathrm{mg} / \mathrm{kg}$ of metformin (84.76\%) [34]. Moreover, compared to the histopathology of the pancreas in the diabetic control group, atrophy and 
abnormalities of the nuclei and the cytoplasm of pancreatic cells have been significantly suppressed with the treatment of ethanol $(150 \mathrm{mg} / \mathrm{kg})$, aqueous $(300 \mathrm{mg} / \mathrm{kg})$ extracts, and metformin [34]. Further, the brown seaweeds Padina boergesenii and Padina tetrastromatica have shown in vivo antidiabetic activities in streptozotocin-induced diabetic rats. Oral administration of the aqueous extract of $P$. boergesenii increased the activity of glycolytic enzymes and decreased the activity of gluconeogenic enzymes in diabetic rats compared to the glibenclamide treatment [35].

Fucus vesiculosus is a brown alga with prominent antidiabetic activities. According to the ultra-high-pressure liquid chromatography coupled to mass spectrometry (UHPLCMS) analysis, the ethyl acetate fraction of Fucus vesiculosuswas reported to have phlorotannins such as fucols, fucophlorethols, fuhalols, fucofurodiphlorethol, fucofurotriphlorethol, and fucofuropentaphlorethol which showed a promising antidiabetic activity through the inhibitory activity of $\alpha$-glucosidase $\left(\mathrm{IC}_{50}: 0.82 \pm 0.05 \mu \mathrm{g} / \mathrm{ml}\right.$ : acarbose $\mathrm{IC}_{50}: 206.6 \pm$ $25.1 \mu \mathrm{g} / \mathrm{ml}$ ) and $\alpha$-amylase $\left(\mathrm{IC}_{50}: 2.8 \pm 0.3 \mu \mathrm{g} / \mathrm{ml}\right.$ : acarbose $\mathrm{IC}_{50}: 0.7 \pm 0.2 \mu \mathrm{g} / \mathrm{ml}$ ) enzymes [36]. In addition to the phlorotannins, Fucus vesiculosus produce fucoidans and Shan et al. [37] evaluated the $\alpha$-glucosidase inhibitory activity of fucoidan extracted from a brown alga Fucus vesiculosus and was reported to have the highest $\alpha$-glucosidase inhibitory effect with $\mathrm{IC}_{50}$ of $67.9 \mu \mathrm{g} / \mathrm{ml}$ compared to the standard drug acarbose $\left(\mathrm{IC}_{50}: 1000 \mu \mathrm{g} / \mathrm{ml}\right)$. Significant reduction of fasting blood glucose and glycosylated haemoglobin levels were also observed in fucoidan extracted from F. vesiculosus-treated diabetes mouse group compared to the control group [37].

According to the study conducted by Chin et al. [27], the brown seaweeds, Padina sulcata, Sargassum binderi, and Turbinaria conoides exhibited a potent $\alpha$-glucosidase inhibitory action in different degrees of potential. Among them, the highest inhibitory activity was reported in crude water extract of T. conoides $(67.38 \%)$ at a concentration of $30 \mathrm{mg} / \mathrm{ml}$ compared to the standard acarbose $(76.23 \%)$ at $1 \mathrm{mg} / \mathrm{ml}$ concentration [27]. Further, according to the study conducted in Sri Lanka, the polyphenolic rich extract of Choonospora minima exhibited potent antidiabetic activities through the inhibition of $\alpha$-amylase and $\alpha$-glucosidase enzymes [38].

4.2. Inhibitory Activity of Aldose Reductase (AR). A brown alga Ecklonia stolonifera has been studied by Lee et al. [29], to determine the inhibitory activity of phlorotannins present in ethanol extract, hexane, dichloromethane, ethyl acetate, butanol, and aqueous fractions of Ecklonia stolonifera. Among them, the ethyl acetate fraction (26.63\%) of E. stolonifera inhibited the rat lens aldose reductase more effectively more than other fractions, and further isolation revealed that the inhibitory activity on rat lens aldose reductase was mainly due to the presence of phlorotannins such as 7-phloroeckol and 2-phloroeckol in ethyl acetate fraction [39]. In addition to the phlorotannins, Jung et al. [40], investigated the antidiabetic effect of fucosterol isolated from Ecklonia stolonifera using the inhibitory activity on rat lens aldose reductase and human recombinant aldose reductase enzymes. The results of this study revealed that fucosterols inhibited both the rat lens aldose reductase $\left(\mathrm{IC}_{50}: 18.94 \mu \mathrm{M}\right)$ and human recombinant aldose reductase $\left(\left(\mathrm{IC}_{50}: 18.94 \mu \mathrm{M}\right)\right.$ compared to the positive control quercetin $\left(\mathrm{IC}_{50}: 1.34 \mu \mathrm{M}\right)$. Hence, fucosterol isolated from E. stolonifera has ability to inhibit the intracellular accumulation of sorbitol; hence, it reduces the cataract in diabetic patients.

Laminaria japonica has undergone a taxonomic revision, and it has become Saccharina japonica [41]. The dichloromethane fraction of brown seaweed Saccharina japonica exhibited the inhibitory activity of rat lens aldose reductase enzyme due to the presence of active porphyrin derivatives such as pheophorbide-A and pheophytin-A. The result revealed that pheophorbide- $\mathrm{A}\left(\mathrm{IC}_{50}: 12.31 \mu \mathrm{M}\right)$ exhibited a potent inhibitory activity on rat lens aldose reductase compared to the pheophytin-A [41]. Further determination of chemical structure proved that the inhibitory activity of pheophorbide-A was mainly due to the presence of a carboxyl group without a phytyl group at the $\mathrm{C}-17^{2}$ position of the porphyrin ring. Therefore, the dichloromethane fraction of Saccharina japonica can be used to treat diabetic complications [42]. Further, Peng et al. [26] reported the antidiabetic potential of fucoxanthin isolated from brown seaweeds Eisenia bicyclis and Undaria pinnatifida. According to the results, fucoxanthin competitively inhibited the rat lens aldose reductase and human recombinant aldose reductase.

Moreover, Young et al. [43] studied the inhibitory activity of phlorotannins isolated from the ethyl acetate fraction of the Eisenia bicyclis on human recombinant aldose reductase enzyme compared to the positive control Epalrestat. Further analysis of the ethyl acetate fraction isolated the five compounds which exhibited an aldose reductase inhibitory activity, and among them, phlorofucofuroeckol-A exhibited the significant inhibition on rat lens aldose reductase $\left(\mathrm{IC}_{50}: 6.22 \mu \mathrm{M}\right)$.

4.3. Inhibitory Activity of Angiotensin-Converting Enzymes (ACE). A brown alga, Ecklonia stolonifera, has been studied for its antidiabetic effect and was reported to have important phlorotannins which exhibited an inhibitory activity on angiotensin-converting enzyme (ACE). Among the reported phlorotannins such as eckol, dieckol, and phlorofucofuroeckol-A exhibited a potent inhibitory activity on angiotensin-converting enzymes with $\mathrm{IC}_{50}$ values of $70.82 \pm 0.25 \mu \mathrm{M}, 34.25 \pm 3.56 \mu \mathrm{M}$, and $12.74 \pm 0.15 \mu \mathrm{M}$. Among the isolated phlorotannins, dieckol inhibited the ACE noncompetitively. Hence, Ecklonia stolonifera has the potential to lower the blood pressure in diabetic patients which helps to reduce the long-term diabetic complications [44].

Paiva et al. [45] investigated the inhibitory effect of enzymatic protein hydrolysate of brown seaweed Fucus spiralis on ACE. Three ultrafiltrate fractions of $F$. spiralis were obtained after obtaining the protein hydrolysate with the enzymatic digestion by the mixture of two enymes cellulase and bromelain. The results revealed the potent ACE inhibitory activity in fraction $3\left(\mathrm{IC}_{50}: 0.5 \mathrm{mg} / \mathrm{ml}\right)$ than the fraction $1\left(\mathrm{IC}_{50}\right.$ : $1.85 \mathrm{mg} / \mathrm{ml})$ and fraction $2\left(\mathrm{IC}_{50}: 2 \mathrm{mg} / \mathrm{ml}\right)$ compared to the positive control captopril $\left(\mathrm{IC}_{50}: 0.163 \mathrm{ng} / \mathrm{ml}\right.$ ) mainly due to the amino acid composition and phlorotannins released 
during the enzymatic digestion [45]. Cha et al. [46] reported the ACE inhibitory activity of some Korean brown seaweeds Sargassum fusiforme, Ishige sinicola, Ecklonia cava, and Sargassum horneri. Among them, the highest ACE inhibitory activity was reported in $70 \%$ methanolic extract of Sargassum fusiforme (87\%) and 70\% aqueous extract of E. cava (90\%) compared to others. Further, proteolytic digestion of $70 \%$ aqueous extract of E. cava revealed the presence of peptides which inhibited ACE. For further information, Hizikia fusiforme has undergone a taxonomic revision, and it has become Sargassum fusiforme [47].

In the same way, Vijayan et al. [48] found that the ethyl acetate extraction of Sargassum wightii exhibited the inhibitory activity on angiotensin 1-converting enzyme (ACE). During further analysis, phloroglucinol $\left(\mathrm{IC}_{50}: 56.96 \mu \mathrm{g} / \mathrm{ml}\right)$ was isolated from the ethyl acetate fraction of $\mathrm{S}$. wightii showed the highest inhibitory activity on ACE compared to the reference drug captopril $\left(\mathrm{IC}_{50}: 51.79 \mu \mathrm{g} / \mathrm{ml}\right)$. According to the literature, phlorotannins which contain a low molecular weight exhibited less potency of ACE inhibition, whereas higher molecular weight phlorotannins showed higher potency of ACE inhibition. Hence, the phlorotannins with higher molecular weight such as phlorofucofuroeckolA, 6,6' bieckol, dieckol, and octaphlorethol A exhibited significantly higher ACE inhibition [49].

4.4. Inhibitory Activity of PTP 1B. Eckol, 7-phloroeckol, and phlorofucofuroeckol-A isolated from Eisenia bicyclis, Ecklonia stolonifera, and Ecklonia cava has the ability to inhibit protein tyrosine phosphatase 1B (PTP 1B) enzyme noncompetitively in addition to the inhibitory activity of carbohydrate-hydrolysing enzymes, aldose reductase, and formation of AGE products [50]. Moon et al. [30] evaluated the inhibitory activity of eckol, 7-phloroeckol, and phlorofucofuroeckol-A on the human recombinant PTP $1 \mathrm{~B}$ and revealed that the isolated phlorotannins eckol, 7phloroeckol, and phlorofucofuroeckol-A inhibited PTP 1B enzyme noncompetitively with the highest inhibitory activity of phlorofucofuroeckol-A $\left(\mathrm{IC}_{50}: 0.56 \mu \mathrm{M}\right)$ compared to the 7phloroeckol $\left(\mathrm{IC}_{50}: 2.09 \mu \mathrm{M}\right)$ and eckol $\left(\mathrm{IC}_{50}: 2.64 \mu \mathrm{M}\right)$. Moreover, Ezzat et al. [51] reported the fucosterol present in E. bicyclis and E. stolonifera have the ability to inhibit the PTP 1B enzyme noncompetitively.

In addition, Ali et al. [52] discovered the PTP 1B inhibitory activity of ethanol extract and fractions of brown algae Sargassum serratifolium. According to the results, the hexane fraction $\left(\mathrm{IC}_{50}: 1.83 \mu \mathrm{g} / \mathrm{ml}\right)$ showed the highest inhibitory activity of PTP $1 \mathrm{~B}$ enzyme than the ethanol extract $\left(\mathrm{IC}_{50}: 7.04 \mu \mathrm{g} / \mathrm{ml}\right)$, dichloromethane $\left(\mathrm{IC}_{50}: 6.32 \mu \mathrm{g} / \mathrm{ml}\right)$, ethyl acetate $\left(\mathrm{IC}_{50}: 1.88 \mu \mathrm{g} / \mathrm{ml}\right)$, and butanol $\left(\mathrm{IC}_{50}: 4.87 \mu \mathrm{g} / \mathrm{ml}\right)$ fractions compared to the positive control ursolic acid $\left(\mathrm{IC}_{50}: 1.12 \mu \mathrm{g} / \mathrm{ml}\right)$. Based on the results, active hexane fraction was subjected for compound isolation and three plastoquinones such as sargahydroquinoic acid, sargachromenol, and sargaquinoic acid were identified. Among them, sargahydroquinoic acid was reported to have the highest PTP $1 B$ inhibitory activity with $\mathrm{IC}_{50}$ value of $5.14 \mu \mathrm{g} / \mathrm{ml}$ which can be a potential source for the treatment of type 2 DM [52].
Further, Feng et al. [53] isolated the 12 stigmastane-type steroids from a brown alga Dictyopteris undulata and determined the hypoglycaemic potential by the inhibitory activity of PTP 1B enzyme. Among the isolated compounds, two compounds, namely, (24S)-7b-methoxy-stigmasta-5,28-diene -3b,24-diol and (24S)-7a-methoxy-stigmasta-5,28-diene-3b, 24-diol, were reported to have a potent PTP $1 \mathrm{~B}$ inhibition with the same $\mathrm{IC}_{50}$ value of $1.88 \mu \mathrm{M}$ compared to the positive control oleanolic acid $\left(\mathrm{IC}_{50}: 2.78 \mu \mathrm{M}\right)$. Therefore, these two compounds can be further analysed to discover a new antidiabetic drug.

4.5. Inhibitory Activity of DPP-4 Enzyme. In 2014, Chin et al. [28] tested the antidiabetic potential of Malaysian brown seaweeds using the inhibitory activity of DPP-4 enzymes which is involved in glucose metabolism. The results revealed that the three brown seaweeds, Padina sulcata, Sargassum binderi, and Turbinaria conoides exhibited a potent DPP-4 inhibitory activity in a dose-dependent manner. Further fractionation revealed that the ethanolic precipitate was the most active against the DPP-4 activity. Among them, the most potent inhibitory activity against DPP-4 enzyme was observed in the ethanolic precipitate of $S$. binderi with $\mathrm{IC}_{50}$ of $2.194 \mathrm{mg} / \mathrm{ml}$ compared to the P. sulcata $\left(\mathrm{IC}_{50}: 2.306 \mathrm{mg} / \mathrm{ml}\right.$ ) and T. conoides $\left(\mathrm{IC}_{50}: 3.594 \mathrm{mg} / \mathrm{ml}\right)$.

Sargassum wightii is a brown alga belong to the family Sargassaceae. The ethyl acetate:methanol fraction and chloroform fraction of $S$. wightii has been used to evaluate the antidiabetic potential through the inhibitory activity of the DPP-4 enzyme. The results indicated the highest DPP-4 inhibitory activity from ethyl acetate:methanol fraction $\left(\mathrm{IC}_{50}: 0.013 \mathrm{mg} / \mathrm{ml}\right)$ more than the chloroform fraction $\left(\mathrm{IC}_{50}\right.$ : $0.028 \mathrm{mg} / \mathrm{ml}$ ) compared to the reference drug diprotein-A $\left(\mathrm{IC}_{50}: 0.007 \mathrm{mg} / \mathrm{ml}\right)$. In addition, the ethyl acetate:methanol (2.51 mg GAE/g) and chloroform (2.04 mg GAE/g) fractions are rich in phenolic compounds which might be attributed to the DPP-4 inhibitory activity [54].

Further studies confirmed the ability of a brown alga Turbinaria ornata to inhibit the DPP-4 enzyme. T. ornata is a rich source of fucoids and sulphated polysaccharides and belongs to the family Phaeophyceae. Unnikrishnan et al. [55] investigated the inhibitory activity of the DPP-4 enzyme using five solvent extracts (petroleum ether, benzene, ethyl acetate, acetone, and methanol) of T. ornata. Among the five extracts tested, the methanol extract of $T$. ornata exhibited the highest inhibitory activity $(55.4 \%)$ at $80 \mu \mathrm{g} / \mathrm{ml}$ compared to the standard diprotin A (65\%). Hence, the methanol extract of $T$. ornata can be used to manage the blood glucose level in diabetes patients.

4.6. Inhibitory Activity of the Formation of AGEs. The phlorotannins such as phlorofucofuroeckol-A $\left(\mathrm{IC}_{50}: 2.4 \times\right.$ $10^{3} \mu \mathrm{M}$ ), eckol ( $\left.\mathrm{IC}_{50}: 1.6 \times 10^{3} \mu \mathrm{M}\right)$, phloroglucinol ( $\mathrm{IC}_{50}$ : $2.4 \times 10^{3} \mu \mathrm{M}$ ), fucofuroeckol A ( IC $\left._{50}: 7.4 \times 10^{2} \mu \mathrm{M}\right)$, dieckol $\left(\mathrm{IC}_{50}: 7.4 \times 10^{2} \mu \mathrm{M}\right)$, and $8,8^{\prime}$-bieckol $\left(\mathrm{IC}_{50}: 6.9 \times 10^{2} \mu \mathrm{M}\right)$ isolated from the Ecklonia cava have reported to exhibit the potent inhibitory effect on the formation of fluorescence bound advanced glycation end products compared to the 
TABLE 1: Summary of tested brown algae and possible active agents responsible for the antidiabetes properties.

\begin{tabular}{|c|c|c|c|}
\hline Family & Species & Active agents & Antidiabetic action \\
\hline \multirow{14}{*}{ Lessoniaceae } & \multirow[b]{3}{*}{ Eisenia bicyclis } & Dioxinodehydroeckol, & $\alpha$-glucosidase inhibitor [20] \\
\hline & & 7-phloroeckol & $\begin{array}{c}\text { PTP 1B inhibition } \\
\alpha \text {-glucosidase inhibitor [20] }\end{array}$ \\
\hline & & Fucoxanthin & $\begin{array}{l}\text { PTP 1B inhibition } \\
\text { Aldose reductase inhibition } \\
\text { Aldose reductase } \\
\text { inhibition [26] }\end{array}$ \\
\hline & \multirow[b]{6}{*}{ Ecklonia cava } & Dieckol & $\alpha$-glucosidase inhibitor [43] \\
\hline & & Fucodiphloroethol G & $\alpha$-amylase inhibitor[43] \\
\hline & & $6,6^{\prime}$-Bieckol & PTP 1B inhibition[43] \\
\hline & & 7-Phloroeckol & ACE inhibitor[43] \\
\hline & & 2-phloroeckol & $\begin{array}{c}\alpha \text {-glucosidase inhibitor } \\
\alpha \text {-glucosidase inhibitor[43] }\end{array}$ \\
\hline & & Phlorofucofuroeckol-A & $\begin{array}{l}\alpha \text {-glucosidase inhibitor [30] } \\
\text { PTP 1B inhibition [30] } \\
\text { Aldose reductase inhibition [38] } \\
\text { Aldose reductase inhibition [38] } \\
\quad \alpha \text {-glucosidase inhibitor } \\
\text { PTP 1B inhibition [30] } \\
\text { ACE inhibitor } \\
\text { AGEs inhibition [55] } \\
\text { Aldose reductase inhibition [42] }\end{array}$ \\
\hline & \multirow{5}{*}{ Ecklonia stolonifera } & Phloroglucinol & $\alpha$-glucosidase inhibitor [29] \\
\hline & & Eckol & PTP 1B inhibition $\alpha$-glucosidase inhibitor [29] \\
\hline & & Dieckol & $\begin{array}{c}\alpha \text {-amylase inhibitor } \\
\text { ACE inhibitor[43] }\end{array}$ \\
\hline & & Phlorofucofuroeckol A & $\begin{array}{c}\text { PTP 1B inhibition } \\
\alpha \text {-glucosidase inhibitor [29] } \\
\alpha \text {-amylase inhibitor } \\
\text { PTP 1B inhibition } \\
\text { ACE inhibitor }[43]\end{array}$ \\
\hline & & Fucosterol & $\begin{array}{c}\alpha \text {-glucosidase inhibitor [29] } \\
\text { ACE inhibitor } \\
\text { AGEs inhibition } \\
\text { PTP 1B inhibition } \\
\text { Aldose reductase inhibition [39] }\end{array}$ \\
\hline Ishigeaceae & Ishige okamurae & Diphlorethohydroxycarmalol & $\begin{array}{c}\alpha \text {-glucosidase inhibitor } \\
\alpha \text {-amylase inhibitor [28] }\end{array}$ \\
\hline \multirow{2}{*}{ Sargassaceae } & Myagropsis myagroides & Eckol & $\begin{array}{c}\alpha \text {-glucosidase inhibitor } \\
\alpha \text {-amylase inhibitor [29] }\end{array}$ \\
\hline & Sargassum serratifolium & Sargahydroquinoic acid & $\begin{array}{l}\text { ACE inhibitor PTP 1B inhibition } \\
\text { PTP 1B inhibition [51] }\end{array}$ \\
\hline Fucaceae & Ascophyllum nodosum & Methanol extract & $\begin{array}{c}\alpha \text {-glucosidase inhibitor [31] } \\
\alpha \text {-amylase inhibitor [31] }\end{array}$ \\
\hline \multirow[b]{2}{*}{ Laminariaceae } & \multirow[b]{2}{*}{ Saccharina japonica } & Pheophorbide-A & Aldose reductase inhibition [41] \\
\hline & & Pheophytin-A & $\begin{array}{c}\text { Aldose reductase } \\
\text { inhibition }[41]\end{array}$ \\
\hline Alariaceae & Undaria pinnatifida & Fucoxanthin & Aldose reductase inhibition [26] \\
\hline \multirow{2}{*}{ Dictyotaceae } & \multirow{2}{*}{ Dictyopteris undulata } & $\begin{array}{c}\text { (24S)-7b-methoxy-stigmasta-5, } \\
\text { 28-diene-3b, 24-diol }\end{array}$ & PTP 1B inhibition [52] \\
\hline & & $\begin{array}{l}\text { (24S)-7a-methoxy-stigmasta-5, } \\
\text { 28-diene-3b, 24-diol }\end{array}$ & PTP 1B inhibition [52] \\
\hline
\end{tabular}




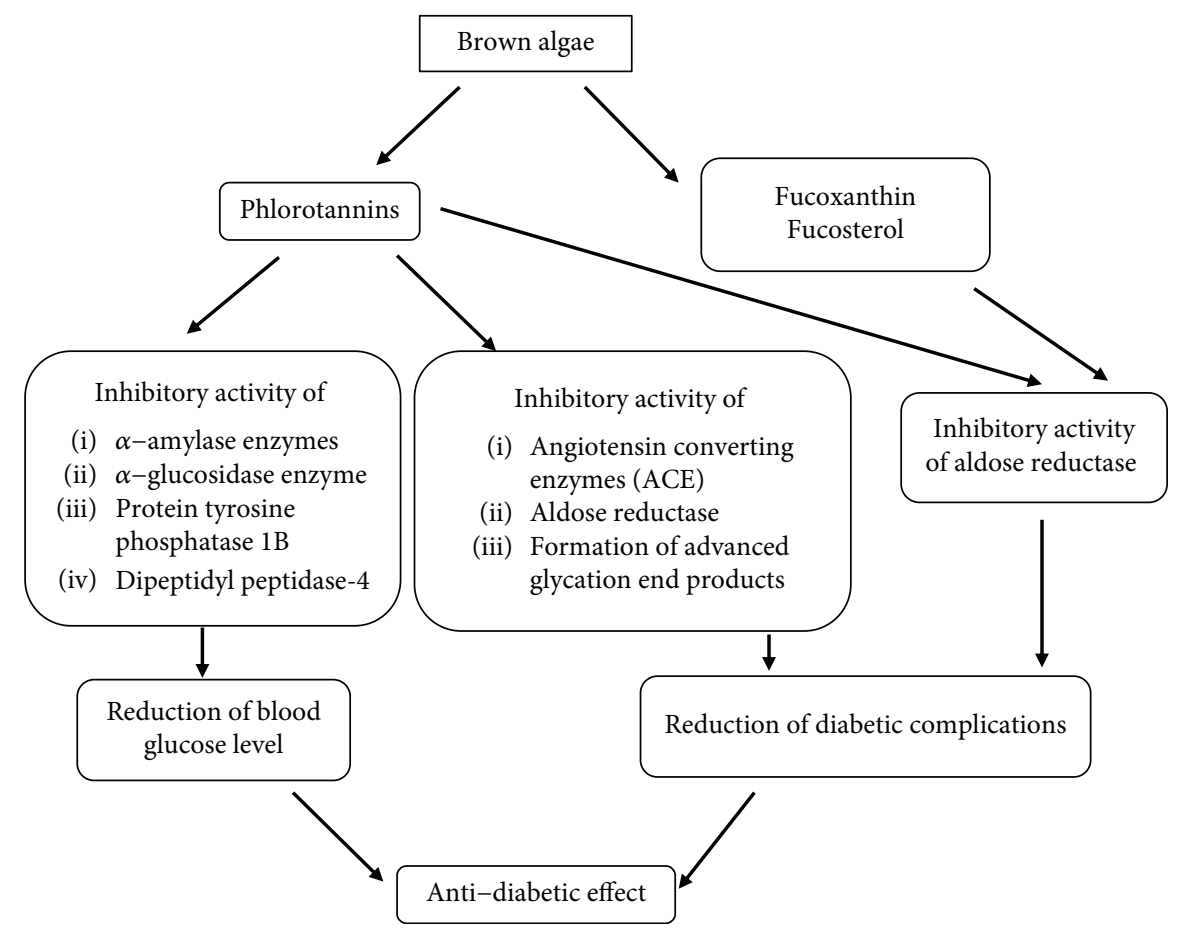

Figure 5: Different antidiabetic mechanisms of active agents of brown algae.

reference drug aminoguanidine hydrochloride $\left(\mathrm{IC}_{50}: 8.1 \times\right.$ $\left.10^{3} \mu \mathrm{M}\right)$ [56].

Further studies on brown algae revealed the presence of phlorotannins in the methanol extract of brown algae such as Padina pavonica, Sargassum polycystum, and Turbinaria ornata inhibits the glucose-induced protein glycation and formation of protein-bound fluorescent advanced glycation end products (AGEs). The results revealed that the phlorotannins present in $P$. pavonica has a potent ability to inhibit the formation of advanced glycation end products $\left(\mathrm{IC}_{50}\right.$ : $15.16 \pm 0.26 \mu \mathrm{g} / \mathrm{ml})$ than $S$. polycystum $\left(\mathrm{IC}_{50}: 35.245 \pm 2.3\right.$ $\mu \mathrm{g} / \mathrm{ml}$ ) and $T$. ornata $\left(\mathrm{IC}_{50}: 22.7 \pm 0.3 \mu \mathrm{g} / \mathrm{ml}\right)$ compared to the standard thiamine $\left(\mathrm{IC}_{50}: 263 \mu \mathrm{g} / \mathrm{ml}\right)$ and phloroglucinol $\left(\mathrm{IC}_{50}: 222.33 \mu \mathrm{g} / \mathrm{ml}\right)$ [57]. In addition, further in vivo studies confirmed the hypoglycaemic effect of phlorotannins $(100 \mu \mathrm{l})$ present in brown algae $P$. pavonica, S. polycystum, and $T$. ornata which exhibited the inhibitory activity on the formation of AGEs in Caenorhabditis elegans (a species of nematode) with induced hyperglycaemia [57].

Liu et al. [58] studied the inhibitory activity on the formation of advanced glycation end products by the phlorotannins present in acetone extract and different fractions of brown algae Fucus vesiculosus. The present study results indicated the higher phlorotannin content in ethyl acetate fraction (115.46 mg phloroglucinol equivalent/g) compared to the acetone extract ( $42.29 \mathrm{mg}$ phloroglucinol equivalent/g) and other fractions. Further, subfractions of ethyl acetate fraction revealed the presence of higher phlorotannin content and (133.81 mg phloroglucinol equivalent/g) and antiglycation activity $\left(\mathrm{EC}_{50}: 0.045 \mathrm{mg} / \mathrm{ml}\right)$ of subfraction 1 compared to phloroglucinol $\left(\mathrm{EC}_{50}: 0.068 \mathrm{mg} / \mathrm{ml}\right)$. Thus, the results explained the inhibitory activity of the formation of
AGEs by the phlorotannins present in brown algae. Additionally, the present study has described the significant inhibitory activity on AGE formation by low molecular weight phlorotannins compared to the higher molecular weight phlorotannins. The summary of tested brown algae and possible active agents responsible for the antidiabetes properties are shown in Table 1.

4.7. Effect of Marine Brown Algae on Patients with Type 2 $D M$. Every new medicine and treatments started with volunteers, who have participated in clinical trials. Clinical trials are essential as they provide information for the discovery and development of new drugs. Preclinical studies provide promising data that support to conduct the relevant human studies in addition to the possible risks and early toxicity markers. Considering the results of in vitro and in vivo studies, very limited number of marine brown seaweeds have been used in the clinical trials to determine the efficacy of a particular seaweed for the development of a new drug to treat the patients with type 2 diabetes mellitus.

Ecklonia cava is a marine brown alga that belongs to the family Lessoniaceae which has been used to conduct the human studies as it provides strong evidence of in vitro and in vivo antidiabetic potential. A clinical trial conducted by Guzman et al. [59] found that the dieckol extract of brown alga Ecklonia cava has ability to reduce the postprandial blood glucose level significantly. In addition, Shin et al. [60] found that the phlorotannins extracted from E. cava exhibited strong antioxidant potential which helps to reduce the oxidative stress-induced complications of diabetes. Ascophyllum nodosum and Fucus vesiculosus are two brown algae belonging to the family Fucaceae, and Guzmán et al. [59] 
revealed that the ability of a commercial mixture of Ascophyllum nodosum and Fucus vesiculosus to inhibit alpha-amylase and alpha-glucosidase activity after 3 hours of ingestion. Moreover, the consumption of $500 \mathrm{mg}$ and $2000 \mathrm{mg}$ of brown seaweed Fucus vesiculosus did not affect the postprandial blood glucose and postprandial insulin levels in healthy volunteers [61].

Further clinical studies revealed the physiological effect of seaweed supplementation of the species from genus Laminaria decreased the fasting blood glucose and two hours postprandial blood glucose levels in patients with type 2 diabetes (control: $254.4 \pm 22.8 \mathrm{mg} / \mathrm{dl}$ and seaweed supplementation: $203.1 \pm 12.3 \mathrm{mg} / \mathrm{dl}$ ) without affecting the glycated haemoglobin level [62]. Undaria pinnatifida is an edible brown alga belonging to the family Alariaceae. According to a clinical trial conducted by Shannon and Abu-ghannam [63] found that the daily supplementation of Undaria pinnatifida balanced the blood glucose levels in patients with type 2 diabetes mellitus. In addition, Sharifuddin et al. [64] found that the consumption of rice-based breakfast supplemented by Undaria pinnatifida reduced the postprandial blood glucose concentration in healthy volunteers.

Considering the clinical trials, unfortunately, few clinical trials were conducted so far to determine the antidiabetic potential of brown seaweed due to the lack of efficacy, lack of funding to complete the clinical trial, issues with safety, problems with sample size during recruitment and retention of patients, etc. As most of the marine brown seaweeds provide strong evidence from the preclinical trial due to the presence of phlorotannins and other bioactive compounds, researchers should be encouraged to conduct the clinical trial to search a novel drug that may be a benefit for the patients with type 2 diabetes mellitus.

\section{Conclusion}

Brown algae are a rich source of bioactive compounds which exhibit significant health-promoting properties. Among them, phlorotannins have been identified in most of the studied brown algal species with most potential applications as an antidiabetic agent in addition to the fucoxanthin, fucosterol, and sulphated polysaccharides. From the available 15002000 brown algal species, a limited number of brown algal species have been studied worldwide to determine their antidiabetic effects. Among them, most brown algal species from family Lessoniaceae has been studied for their antidiabetic activity in addition to the brown algal species from family Ishigeaceae, Sargassaceae, Fucaceae, Laminariaceae, Alariaceae, and Dictyotaceae. So far, only one brown algal species from family Scytosiphonaceae has been studied in Sri Lanka to determine their antidiabetic effect as mentioned above. In this review, we have discussed about the different antidiabetic mechanisms of phlorotannins and other bioactive compounds present in marine brown algal species (Figure 5). Taken together, the search for an effective antidiabetic drug from the phlorotannins is present in brown algal benefits for the patients with type 2 diabetes. Therefore, extensive researches should be developed to utilize the marine flora more efficiently to determine the therapeutic agents that may be a benefit for the patients with type 2 diabetes.

\section{Conflicts of Interest}

The authors declare that there is no conflict of interests.

\section{References}

[1] W. Kooti, M. Farokhipour, Z. Asadzadeh, D. Ashtary-Larky, and M. Asadi-Samani, "The role of medicinal plants in the treatment of diabetes: a systematic review," Electronic Physician, vol. 8, no. 1, pp. 1832-1842, 2016.

[2] R. Bhattacharjee, A. Mitra, B. Dey, and A. Pal, "Exploration of anti-diabetic potentials amongst marine species-a mini review," Indo Global Journal of Pharmaceutical Sciences, vol. 4, no. 2, pp. 65-73, 2014.

[3] F. Zaccardi, D. R. Webb, T. Yates, and M. J. Davies, "Pathophysiology of type 1 and type 2 diabetes mellitus: a 90-year perspective," Postgraduate Medical Journal, vol. 92, no. 1084, pp. 63-69, 2016.

[4] Z. Wang, J. Wang, and P. Chan, "Treating type 2 diabetes mellitus with traditional Chinese and Indian medicinal herbs," Evidence-Based Complementary and Alternative Medicine, vol. 2013, Article ID 343594, 17 pages, 2013.

[5] World Health Organization, “Diabetes,” 2016, May 2019, http://www.who.int/mediacentre/factsheets/fs312/en/.

[6] A. K. Jenum, L. M. Diep, G. Holmboe-Ottesen, I. M. K. Holme, B. N. Kumar, and K. I. Birkeland, "Diabetes susceptibility in ethnic minority groups from Turkey, Vietnam, Sri Lanka and Pakistan compared with Norwegians - the association with adiposity is strongest for ethnic minority women," BMC Public Health, vol. 12, no. 1, p. 150, 2012.

[7] American Diabetes Association, "Diagnosis and classification of diabetes mellitus," Diabetes Care, vol. 36, Supplement_1, pp. S67-S74, 2013.

[8] S. E. Kahn, R. L. Hull, and K. M. Utzschneider, "Mechanisms linking obesity to insulin resistance and type 2 diabetes," Nature, vol. 444, no. 7121, pp. 840-846, 2006.

[9] A. D. Mooradian, "Dyslipidemia in type 2 diabetes mellitus," Nature Clinical Practice Endocrinology \& Metabolism, vol. 5, no. 3, pp. 150-159, 2009.

[10] J. J. Marín-Peñalver, I. Martín-Timón, C. Sevillano-Collantes, and F. J. . Cañizo-Gómez, "Update on the treatment of type 2 diabetes mellitus," World Journal of Diabetes, vol. 7, no. 17, pp. 354-395, 2016.

[11] C. Wang, "The relationship between type 2 diabetes mellitus and related thyroid diseases," Journal of Diabetes Research, vol. 2013, Article ID 390534, 9 pages, 2013.

[12] P. S. Unnikrishnan and M. A. Jayasri, "Marine algae as a prospective source for antidiabetic compounds - a brief review," Current Diabetes Reviews, vol. 14, no. 3, pp. 237-245, 2018.

[13] S. Gupta and N. Abu-Ghannam, "Bioactive potential and possible health effects of edible brown seaweeds," Trends in Food Science \& Technology, vol. 22, no. 6, pp. 315-326, 2011.

[14] D. A. Hinnen, "Therapeutic options for the management of postprandial glucose in patients with type 2 diabetes on basal insulin," Clinical Diabetes: a publication of the American Diabetes Association, vol. 33, no. 4, pp. 175-180, 2015.

[15] S. S. Nair, V. Kavrekar, and A. Mishra, "In-vitro studies on alpha amylase and alpha glucosidase inhibitory activities of 
selected plant extractso," European Journal of Experimental Biology, vol. 3, no. 1, pp. 128-132, 2013.

[16] B. Dey, A. Mitra, P. Katakam, and R. K. Singla, "Exploration of natural enzyme inhibitors with hypoglycemic potentials amongst Eucalyptus Spp. by in vitro assays," World Journal of Diabetes, vol. 5, no. 2, pp. 209-218, 2014.

[17] C. F. Deacon, "Physiology and pharmacology of DPP-4 in glucose homeostasis and the treatment of type 2 diabetes," Frontiers in Endocrinology, vol. 10, p. 80, 2019.

[18] W. H. Tang, K. A. Martin, and J. Hwa, "Aldose reductase, oxidative stress, and diabetic mellitus," Frontiers in Pharmacology, vol. 3, p. 87, 2012.

[19] B. Amann, R. Tinzmann, and B. Angelkort, "ACE inhibitors improve diabetic nephropathy through suppression of renal MCP-1," Diabetes Care, vol. 26, no. 8, pp. 2421-2425, 2003.

[20] S. S. Abdelsalam, H. M. Korashy, A. Zeidan, and A. Agouni, "The role of protein tyrosine phosphatase (PTP) -1B in cardiovascular disease and its interplay with insulin resistance," Biomolecules, vol. 9, no. 7, 286 pages, 2019.

[21] J. Bakke and F. G. Haj, "Protein-tyrosine phosphatase 1B substrates and metabolic regulation," Seminars in Cell \& Developmental Biology, vol. 37, pp. 58-65, 2016.

[22] V. P. Singh, A. Bali, N. Singh, and A. S. Jaggi, "Advanced glycation end products and diabetic complications," The Korean Journal of Physiology \& Pharmacology, vol. 18, no. 1, pp. 1-14, 2014.

[23] S. M. Hamed, A. A. Abd el-Rhman, N. Abdel-Raouf, and I. B. M. Ibraheem, "Role of marine macroalgae in plant protection \& improvement for sustainable agriculture technology," Beni-Suef University Journal of Basic and Applied Sciences, vol. 7, no. 1, pp. 104-110, 2018.

[24] A. M. Cikoš, S. Jokić, D. Šubarić, and I. Jerković, "Overview on the application of modern methods for the extraction of bioactive compounds from marine macroalgae," Marine Drugs, vol. 16, no. 10, p. 348, 2018.

[25] T. Wang, R. Jónsdóttir, H. Liu et al., “Antioxidant capacities of phlorotannins extracted from the brown algae Fucus vesiculosus," Journal of Agricultural and Food Chemistry, vol. 60, no. 23, pp. 5874-5883, 2012.

[26] J. Peng, J. P. Yuan, C. F. Wu, and J. H. Wang, "Fucoxanthin, a marine carotenoid present in brown seaweeds and diatoms: metabolism and bioactivities relevant to human health," Marine Drugs, vol. 9, no. 10, pp. 1806-1828, 2011.

[27] Y. X. Chin, P. E. Lim, C. A. Maggs, S. M. Phang, Y. Sharifuddin, and B. D. Green, "Anti-diabetic potential of selected Malaysian seaweeds," Journal of Applied Phycology, vol. 27, no. 5, pp. 2137-2148, 2014.

[28] H. W. Yang, K. H. N. Fernando, J. Y. Oh, X. Li, Y. J. Jeon, and B. M. Ryu, "Anti-obesity and anti-diabetic effects of Ishige okamurae," Marine Drugs, vol. 17, no. 4, p. 202, 2019.

[29] S. Lee and Y. Jeon, "anti-diabetic effects of brown algae derived phlorotannins, marine polyphenols through diverse mechanisms," Fitoterapia, vol. 86, pp. 129-136, 2013.

[30] H. E. Moon, M. N. Islam, B. R. Ahn et al., "Protein tyrosine phosphatase $1 \mathrm{~B}$ and $\alpha$-glucosidase inhibitory Phlorotannins from edible Brown Algae, Ecklonia stolonifera and Eisenia bicyclis," Bioscience, Biotechnology, and Biochemistry, vol. 75, no. 8, pp. 1472-1480, 2014.

[31] F. Nwosu, J. Morris, V. A. Lund, D. Stewart, H. A. Ross, and G. J. McDougall, "Anti-proliferative and potential antidiabetic effects of phenolic-rich extracts from edible marine algae," Food Chemistry, vol. 126, no. 3, pp. 1006-1012, 2011.
[32] A. Husni, T. Pratiwi, A. G. Samudra, and A. E. Nugroho, "In vitro antidiabetic activity of Sargassum hystrix and Eucheuma denticulatum from Yogyakarta Beach of Indonesia," Proceedings of the Pakistan Academy of Sciences: B. Life and Environmental Sciences, vol. 55, no. 3, pp. 1-8, 2018.

[33] T. L. Gotama, A. Husni, and Ustadi, "Antidiabetic activity of Sargassum hystrix extracts in streptozotocin-induced diabetic rats," Preventive Nutrition and Food Science, vol. 23, no. 3, pp. 189-195, 2018.

[34] M. Motshakeri, M. Ebrahimi, Y. M. Goh, H. H. Othman, M. Hair-Bejo, and S. Mohamed, "Effects of brown seaweed (Sargassum polycystum) extracts on kidney, liver, and pancreas of type 2 diabetic rat model," Evidence-Based Complementary and Alternative Medicine, vol. 2014, Article ID 379407, 11 pages, 2014.

[35] P. Senthilkumar, S. Sudha, and S. Prakash, "Antidiabetic activity of aqueous extract of Padina boergesenii in streptozotocininduced diabetic rats," International Journal of Pharmacy and Pharmaceutical Sciences, vol. 6, no. 5, pp. 418-422, 2014.

[36] M. D. Catarino, A. M. S. Silva, N. Mateus, and S. M. Cardoso, "Optimization of phlorotannins extraction from Fucus vesiculosus and evaluation of their potential to prevent metabolic disorders," Marine Drugs, vol. 17, no. 3, p. 162, 2019.

[37] X. Shan, X. Liu, J. Hao et al., "In vitro and in vivo hypoglycemic effects of brown algal fucoidans," International Journal of Biological Macromolecules, vol. 82, pp. 249-255, 2016.

[38] M. D. T. L. Gunathilaka, D. Peiris, P. Ranasinghe, and K. W. Samarakoon, "In-vitro anti-diabetic activity of polyphenolic rich extract from marine brown algae Choonospora minima (Hering 1841)," in 12th International Conference of KDU, p. 185, General Sri John Kotelawala University, Sri Lanka, 2019.

[39] H. A. Jung, N. Y. Yoon, M. H. Woo, and J. S. Choi, "Inhibitory activities of extracts from several kinds of seaweeds and phlorotannins from the brown alga Ecklonia stolonifera on glucosemediated protein damage and rat lens aldose reductase," Fisheries Science, vol. 74, no. 6, pp. 1363-1365, 2008.

[40] O. N. Selivanova, G. G. Zhigadlova, and G. I. Hansen, "Revision of the systematics of algae in the order Laminariales (Phaeophyta) from the far-eastern seas of Russia on the basis of molecular phylogenetic data," Russian Journal of Marine Biology, vol. 33, no. 5, pp. 278-289, 2007.

[41] H. A. Jung, M. N. Islam, C. M. Lee et al., "Kinetics and molecular docking studies of an anti-diabetic complication inhibitor fucosterol from edible brown algae Eisenia bicyclis and Ecklonia stolonifera," Chemico-Biological Interactions, vol. 206, no. 1, pp. 55-62, 2013.

[42] Y. K. Son, S. E. Jin, H. R. Kim, H. C. Woo, H. A. Jung, and J. S. Choi, "Inhibitory activities of the edible brown alga Laminaria japonica on glucose-mediated protein damage and rat lens aldose reductase," Fisheries Science, vol. 77, no. 6, pp. 10691079, 2011.

[43] J. Y. Lee, S. M. Kim, W. S. Jung et al., "Phlorofucofuroeckol-A, a potent inhibitor of aldo-keto reductase family 1 member b10 , from the edible brown alga Eisenia bicyclis," Journal of the Korean Society for Applied Biological Chemistry, vol. 55, no. 6, pp. 721-727, 2012.

[44] N. V. Thomas and S. K. Kim, "Potential pharmacological applications of polyphenolic derivatives from marine brown algae," Environmental Toxicology and Pharmacology, vol. 32, no. 3, pp. 325-335, 2011. 
[45] L. Paiva, E. Lima, A. Neto, and J. Baptista, "Angiotensin Iconverting enzyme (ACE) inhibitory activity, antioxidant properties, phenolic content and amino acid profiles of Fucus spiralis L. Protein Hydrolysate Fractions," Marine Drugs, vol. 15, no. 10, pp. 311-318, 2017.

[46] V. Stiger, T. Horiguchi, T. Yoshida, A. W. Coleman, and M. Masuda, "Phylogenetic relationships within the genus Sargassum (Fucales, Phaeophyceae), inferred from ITS-2 nrDNA, with an emphasis on the taxonomic subdivision of the genus," Phycological Research, vol. 51, no. 1, pp. 1-10, 2020.

[47] S.-H. Cha, G.-N. Ahn, S.-J. Heo et al., "Screening of extracts from marine green and brown algae in Jeju for potential marine angiotensin-I converting enzyme (ACE) inhibitory activity," Journal of the Korean Society of Food Science and Nutrition, vol. 35, no. 3, pp. 307-314, 2006.

[48] R. Vijayan, L. Chitra, S. Penislusshiyan, and T. Palvannan, "Exploring bioactive fraction of Sargassum wightii: In vitro elucidation of angiotensin-I-converting enzyme inhibition and antioxidant potential," International Journal of Food Properties, vol. 21, no. 1, pp. 674-684, 2018.

[49] L. Paiva, E. Lima, A. I. Neto, and J. Baptista, “Angiotensin Iconverting enzyme (ACE) inhibitory activity of Fucus spiralis macroalgae and influence of the extracts storage temperature-A short report," Journal of Pharmaceutical and Biomedical Analysis, vol. 131, pp. 503-507, 2016.

[50] G. Lopes, P. Andrade, and P. Valentão, "Phlorotannins: towards new pharmacological Interventions for Diabetes Mellitus Type 2," Molecules, vol. 22, no. 1, p. 56, 2017.

[51] S. M. Ezzat, M. H. El Bishbishy, S. Habtemariam et al., "Looking at marine-derived bioactive molecules as upcoming anti-diabetic agents: a special emphasis on PTP1B inhibitors," Molecules, vol. 23, no. 12, article 3334, 2018.

[52] M. Y. Ali, D. H. Kim, S. H. Seong, H. R. Kim, H. Jung, and J. S. Choi, " $\alpha$-Glucosidase and protein tyrosine phosphatase $1 \mathrm{~B}$ inhibitory activity of plastoquinones from marine brown alga Sargassum serratifolium," Marine Drugs, vol. 15, no. 12, p. 368, 2017.

[53] M. T. Feng, T. Wang, A. H. Liu et al., "PTP1B inhibitory and cytotoxic C-24 epimers of $\Delta^{28}$-24-hydroxy stigmastane-type steroids from the brown alga Dictyopteris undulata Holmes," Phytochemistry, vol. 146, pp. 25-35, 2018.

[54] A. Maneesh, K. Chakraborty, and F. Makkar, "Pharmacological activities of brown seaweed Sargassum wightii (Family Sargassaceae) using different in vitro models," International Journal of Food Properties, vol. 20, no. 4, pp. 931-945, 2017.

[55] P. S. Unnikrishnan, K. Suthindhiran, and M. A. Jayasri, "Inhibitory potential of Turbinaria ornata against key metabolic enzymes linked to diabetes," BioMed Research International, vol. 2014, Article ID 783895, 10 pages, 2014.

[56] S. Sugiura, Y. Minami, R. Taniguchi et al., "Evaluation of antiglycation activities of phlorotannins in human and bovine serum albumin-methylglyoxal models," Natural Product Communications, vol. 12, no. 11, 2017.

[57] G. Shakambari, B. Ashokkumar, and P. Varalakshmi, "Phlorotannins from brown algae: inhibition of advanced glycation end products formation in high glucose induced Caenorhabditis elegans," Indian Journal of Experimental Biology, vol. 53, no. 6, pp. 371-379, 2015.

[58] H. Liu and L. Gu, "Phlorotannins from brown algae (Fucus vesiculosus) inhibited the formation of advanced glycation endproducts by scavenging reactive carbonyls," Journal of
Agricultural and Food Chemistry, vol. 60, no. 5, pp. 1326$1334,2012$.

[59] M. Gómez-Guzmán, A. Rodríguez-Nogales, F. Algieri, and J. Gálvez, "Potential role of seaweed polyphenols in cardiovascular-associated disorders," Marine Drugs, vol. 16, no. 8, p. 250, 2018.

[60] H. C. Shin, S. H. Kim, Y. Park, B. H. Lee, and H. J. Hwang, "Effects of 12-week oral supplementation of Ecklonia cava polyphenols on anthropometric and blood lipid parameters in overweight Korean individuals:a double-blind randomized clinical trial," Phytotherapy Research, vol. 26, no. 3, pp. 363368, 2012.

[61] M. Murray, A. Dordevic, L. Ryan, and M. Bonham, "The impact of a single dose of a polyphenol-rich seaweed extract on postprandial glycaemic control in healthy adults: a randomised cross-over trial," Nutrients, vol. 10, no. 3, p. 270, 2018.

[62] M. S. Kim, J. Y. Kim, W. H. Choi, and S. S. Lee, "Effects of seaweed supplementation on blood glucose concentration, lipid profile, and antioxidant enzyme activities in patients with type 2 diabetes mellitus," Nutrition Research and Practice, vol. 2, no. 2, pp. 62-67, 2008.

[63] E. Shannon and N. Abu-ghannam, "Seaweeds as nutraceuticals for health and nutrition," Phycologia, vol. 58, no. 5, pp. 563577, 2019.

[64] Y. Sharifuddin, Y. X. Chin, P. E. Lim, and S. M. Phang, "Potential bioactive compounds from seaweed for diabetes management," Marine Drugs, vol. 13, no. 8, pp. 5447-5491, 2015. 